\title{
Reflections on the reform of teaching material management in
}

\section{Colleges and Universities}

\author{
Genlian Zhang ${ }^{1, a}$ \\ ${ }^{1}$ Jilin business and technology college , Jilin, China \\ a24683708@qq.com
}

\begin{abstract}
Teaching material is the knowledge carrier of teaching content and teaching method, it is the basic tool for teaching, and also the important guarantee for deepening the reform of education and teaching and cultivating innovative talents. The management of teaching materials has a direct impact on the supply, circulation, use and construction of teaching materials. This paper puts forward some suggestions combined with the present situation of teaching material management in the new situation from the teaching material management, teaching material management system construction, and so on.
\end{abstract}

Keyword: Teaching material management; teaching material construction

Teaching material construction is a basic construction of the school. Teaching material management is an important guarantee for the construction of teaching materials. The two plays an important role in improving the teaching quality, stabilizing the teaching order and promoting the teaching reform. The implementation of the teaching process to reflect the requirements of the teaching plan in addition and the implementation of the teaching plan, teaching material occupy an important position. If there is no teaching materials, teaching can't be carried out, the teaching plan can't be completed, the normal teaching order can't be maintained[1]. The teaching material management is in the teaching material construction process according to the teaching material construction duty, the characteristic and the rule carries on the management, it is the education science and the management science concrete application. It is particularly important and more urgent with the development of social market economy how to build a new management system and promote the reform of teaching material management and system construction. This paper puts forward some suggestions on the new situation of teaching material management.

\section{Problems in teaching material management.}

1.1The national teaching material management standard is few and not easy to carry out. The construction of teaching material is mainly focused on the curriculum construction, and the declaration of excellent teaching materials is emphasized from the point of view of the national and provincial management documents in recent years. Teaching materials management provisions are relatively old, can't keep pace with the times, so that some of the blind management of the school, the grass-roots teaching material management department at a loss, a dilemma[2]. 
1.2 market supply and demand changes in the environment, so that the challenges of teaching supplies. In the past, a single supply of school textbooks has been broken, the original Xinhua Bookstore unified issue, and now the major publishers compete for the teaching material market, there are many books distribution companies also operate textbooks. The competition pattern of the teaching material market has been formed, which provides a certain space for the majority of teachers to optimize teaching materials, and also brings great challenges to the management of teaching materials.

1.3 The pressure of teaching material management caused by school expansion. The colleges and universities adjusted personnel training objectives and changed the original training standards after 1998. The goal of personnel training is to adapt, compete and innovate. From the beginning of 1999, colleges and universities have autonomy, enrollment expansion, control more difficult, and sometimes the number of students is different from the number of plans. If the book is scheduled to be more, inventory backlog and cash flow difficulties. Fewer textbooks, then some students may not have textbooks. Therefore, the management of teaching materials in Colleges and universities should be reformed to meet the needs of the reform and development of colleges and universities[3].

1.4 University internal management is not in place. Firstly, the systematic and scientific understanding of textbooks is not enough. Teaching materials suppliers do not consider the level of practical teaching materials. If blindly pursue high level, high grade, it may be out of touch with the training objectives. Second, the management of teaching materials is not appropriate. Teaching materials, such as self compiled lectures, experimental practice guide books and exercises, etc., are usually prepared and printed by the teachers themselves, and the teaching materials managers are not strict with the compilation, printing and selection of supplementary materials. Third, the teaching material management mode is single, and the adaptability is poor. Teaching material supply and teaching management. Teaching materials managers do not study the laws of teaching, do not pay attention to the development of various disciplines, do not understand the scientific content of teaching materials, etc. Fourth, the lack of teaching material management activity is not enough. Teaching materials management department only play its administrative functions, does not reflect the management functions. The economic benefits of teaching materials management and teaching materials managers have been separated. It is a kind of service management system which there is no incentive mechanism. Fifth, the teaching material management information level is low. Management personnel can't well adapt to the requirements of the situation. Part of the management software is only for the nature of the book distribution bookstore. The management software system with the characteristics of different schools is not mature. Sixth, the current teaching materials management personnel qualifications and ability is low, the work efficiency is not high. The teaching material management personnel who only have management experience can't meet the requirements of modern teaching management.

1.5 Textbook pricing is too high. The textbook editing and publishing department issued by the publishing houses are generally high priced, and students can't afford it. 
School teaching materials service sector has entered the semester before the semester teaching materials, but students didn't get the textbook management department. Students may copy textbooks but do not buy textbooks, which seriously affect the teaching[4].

\section{Suggestions on the reform of teaching material management}

2.1 attach importance to the research of teaching material management and intensify the reform. Actively explore the reform of teaching materials management In accordance with the requirements of all levels of management. We can grasp the current situation, development trend and existing problems from the process of the formation of teaching materials. We can grasp the current situation, development trend and existing problems in the process of compiling textbooks in the process of compiling textbooks. Through scientific research, we can find new phenomena, reveal new laws, establish new theories and find new ways to make people acquire new knowledge, further update, enrich the content of teaching materials and improve the quality of teaching materials. Teaching material management can't use a unified management model, but the need for flexible and diverse, change the concept and strengthen awareness. Through the discussion of the new situation of the teaching material management methods, find out suitable for their own development management[5].

2.2 Establish and improve the rules and regulations of the management of teaching materials. The Ministry of education puts forward some opinions on strengthening the construction of teaching materials in Colleges and universities[6]. Improve the supply of teaching materials, and gradually straighten out the relationship between the various aspects. Establish and improve the rules and regulations, the focus of teaching material management is not the experience of modern management. The modernization of college teaching material management system has played a powerful role in promoting. In order to make the teaching management work standardization, we must start from the system level to establish a new system, so that each work should have. the system must be carried out strictly in the daily teaching material management work, so that the teaching material management system can really be carried out and play its due role After the establishment of the complete rules and regulations.

2.3 Rationalize the relationship between supply and demand of the quality of teaching. The goal of teaching material construction and teaching material management is to improve teaching quality. However, the quality control is a complex problem. There are many factors that affect the quality of teaching materials, such as the problems of teaching materials, teaching materials management, etc. The supply of teaching materials is an important part of the teaching material management. Strive to do before the hand and resolutely put an end to the illegal publication of textbooks into the classroom In order to do a good job in the supply of teaching materials., we can use the "purchase and sale contract" system In the supply of teaching materials that the teaching material management department signed a contract according to the actual needs of the students. This can overcome the blindness of textbook ordering and reduce the backlog of textbooks. The textbook Distribution Department of the 
school as a general platform for the distribution of the school textbooks should effectively rationalize the supply and demand of textbooks. The introduction of competition mechanism can reduce the cost of teaching materials and make the most beneficial to students under the premise of ensuring the quality of teaching materials and the book before class. The application of teaching materials, and now it is not necessarily applicable a few years ago, especially in the field of social science teaching materials change is greater. With the development of the situation, the textbooks used a few years ago are not necessarily applicable now. Especially teaching materials change is greater in the field of social science. For example, the understanding about the characteristics of China law of the development of socialist market economy and the reform of the economic system of the problem, they are also in development, each period has a different formulation, not in today's formulation as a standard to measure a few years ago, the quality of teaching materials.

2.4 establish a market-oriented operating mechanism to adapt to market choice. The school teaching material service department is the main body of the teaching material. They should carry on the teaching material construction and the teaching material research. In the teaching material service department, the school set up to adapt to the market operation of the book distribution of corporate entities who conduct the procurement and supply of teaching materials. The teaching material budget is independent accounting, which is helpful to mobilize the enthusiasm and initiative of the teaching staff, reduce the cost of the book entry, accelerate the capital turnover, and give full play to the benefits of the teaching materials. At the same time, we should strengthen the service consciousness in the teaching material management, and realize the service for the teachers and students. The basic teaching material department should change from the service type to the service type for serving the teaching better in the environment of market economy. Not only do their own services work, but also carry out business activities. Under the premise of completing the task of publishing and printing of the textbook, we should tap the potential and carry out the external service to achieve the needs.

2.5 Strengthen teachers to prepare teaching materials management, breaking the school underwriting system. In the market economy environment, we should reform the management system. By breaking the "package" word, release the distribution channels. Multi channel distribution. The issuer should carry out various forms of buying and selling activities In order to give full play to the role of market regulation. In recent years, many teachers have published their own teaching materials in order to stabilize the teaching order of the school, train teachers and fill a gap in the teaching materials, and so on. But it also has a negative impact on the backlog of school textbooks. The difficulty of teaching material management has been increased. Part of the scope of teaching materials is small, but the number of its release is large. Part of the knowledge lags behind, affecting the effectiveness of classroom teaching, the occupation of a large number of school textbooks turnover, resulting in a waste of resources. Management departments at all levels should strengthen the leadership of the work of teaching materials publishing, it is necessary to implement the access system, and steadily promote the construction of teaching materials. 


\section{Reference:}

[1] Daikefeng. University Teaching Material Management and the Countermeasures[J]. Science Education Article Collects, 2012.(04):20-22.

[2] LI Yueqiong .On the Innovation of College Teaching Material Managementunder the Background of Information Technology[J]. The Guide of Science \& Education,2016,(06):25-26. [3] GuoJun Xie. Reflections on the management of teaching materials in Colleges and Universities under the credit system[J]. Journal of Guilin College of Aerospace Technology, 2007,(02):94-95+98.

[4] FENG Yun. Preliminary Analysis of College and University Textbook Management[J]. Journal of Guizhou Education University,2016,(02):80-82.

[5] Li Jufang, Zhu GuominOn teaching material management in Colleges and Universities [J]. Journal of Liaoning Educational Administration Institute,2006,(10):22-23.

[6]PENG Li. The Problems Faced by the Construction and Management of University Teaching Materials and the Countermeasures[J]. SCI-TECH INFORMATION DEVELOPMENT \& ECONOMY,2007,(03):247-248. 